\title{
Preservação de documentos especiais
}

\author{
Miriam Paula Manini \\ Universidade de Brasília, Faculdade de Ciência da Informação, Brasília, DF, Brasil \\ mpmanini@uol.com.br
}

Resumo: Este artigo é, antes de tudo, um "manual de primeiros socorros" para profissionais ou interessados que trabalham com acervos compostos por uma diversidade grande de espécies documentais. As informações são fruto de pesquisa bibliográfica e de experiência de trabalho em acervos múltiplos. São abordadas espécies documentais presentes em acervos desde muito antes do advento do digital. São abordadas questões especificamente ligadas aos suportes materiais da informação e não aos seus conteúdos. A parte referente à preservação fotográfica - a mais extensa e importante - é baseada na formação junto ao Centro de Conservação e Preservação Fotográfica, da Fundação Nacional de Arte, no Rio de Janeiro. Os demais materiais (películas, fitas de vídeo e de áudio, discos, objetos e disquetes, entre outros) são abordados de maneira mais econômica pela escassez de informações encontradas. A parte final, Controvérsias Preciosas, é quase um apêndice, que reúne as principais discussões da área que causam dúvidas de qual o melhor procedimento a adotar.

Palavras-chave: Audiovisual; Bens culturais; Conservação documental; Documento sonoro; Fotografia; Películas cinematográficas.

The preservation of special documents

Abstract: This article is, mainly, a kind of a "manual first aid" for professionals interested or working with collections composed of a wide range of documentary species. The information is the result of bibliographic research and work experience with multiple collections. There are questions related to documentary species present in collections before the advent of digital era. There are issues specially concerned to the material supports of information and not its contents. The part concerning photographic preservation - the most extensive and important - is based on training at the Photographic Preservation and Conservation Center, at National Art Foundation, in Rio de Janeiro. Other materials (films, video and audio tapes, disks, diskettes and objects etc.) are addressed in a economic way by paucity of information found. The final part, Dispute Precious, is almost an appendix, which brings the main discussions of the area that cause doubt about the best procedure to adopt.

Keywords: Audiovisual; Cultural heritage; Documentary conservation; Sound document; Photography; Cinematographic films.

\section{La preservación de documentos especiales}

Resumen: Este artículo es ante todo una "manual de primeros auxilios" para los profesionales interesados o que trabajan con colecciones compuestas de una amplia gama de especies documentales. La información es el resultado de la investigación bibliográfica y experiencia laboral con varias tipologías. Están discutidas especies documentales presentes en colecciones mucho antes del advenimiento de la tecnología digital. Específicamente cuestiones se abordan vinculados a los soportes materiales de información y no a su contenido. La parte relativa a la conservación fotográfica - la más extensa e importante - se basa en la formación en el Centro de Conservación y Preservación Conservación Fotográfica, de la Fundación Nacional de Arte, en el Río de Janeiro. Otros materiales (películas, cintas de vídeo y de audio, discos, disquetes y objetos etc.) se tratan de manera más económica por la escasez de información que se encuentra. La parte final, Disputas Preciosas, es casi un apéndice, que reúne a los principales debates de la área que causan duda respecto de cuál es el mejor procedimiento para adoptar.

Palabras clave: Audiovisuales; Bienes culturales; Conservación Documental; Documento de sonido; Fotografía; Películas cinematográficas. 


\section{Introdução}

Nem tudo envelhece.

O brilho púrpuro, sob a água pura, ah, se eu pudesse.

\section{Nem tudo, sentir fica. Fica como fica a magnólia, magnifica.}

Paulo Leminski

Este artigo não pretende preencher a lacuna existente sobre o assunto no Brasil. É antes de tudo, um "manual de primeiros socorros" para profissionais ou interessados que trabalham com acervos compostos por uma diversidade grande de espécies documentais.

Todas as informações aqui contidas são fruto não só da consulta às referências que se apresentam ao final, mas principalmente, de experiência de trabalho em acervos múltiplos. Deve-se enfatizar que serão abordadas espécies documentais presentes em acervos muito antes do advento digital, e que não farão parte deste artigo documentos chamados digitais, assim como não será abordada a preservação digital.

A parte referente à preservação fotográfica foi fortemente baseada na formação junto ao Centro de Conservação e Preservação Fotográfica da Fundação Nacional de Arte $^{1}$ (CCPF/Funarte) no Rio de Janeiro, instituição que, nacional e internacionalmente, entre outras coisas, prepara profissionais da preservação fotográfica.

Deve-se, igualmente, a João Sócrates de Oliveira, conceituado profissional, a noção maior das necessidades de conscientização com relação a essa área apaixonante e, por vezes, tão desvalorizada para a memória, a História e as políticas públicas.

Serão abordadas questões especificamente ligadas aos suportes materiais da informação e não aos seus conteúdos.

A parte inicial, dedicada à fotografia, é a mais extensa e a mais importante. Os demais materiais (películas, fitas de vídeo e de áudio, discos, objetos, disquetes, entre outros) são abordados de maneira mais econômica pela escassez de informações existentes a respeito. Pretende-se, entretanto, dar uma noção inicial de como tratar tais documentos.

\footnotetext{
${ }^{1}$ Disponível em <http://www.funarte.gov.br/preservacaofotografica/>. Acesso em: 07 dez. 2015.
} 
A parte final, Controvérsias Preciosas, é quase um apêndice, que reúne as principais discussões da área que causam dúvidas de procedimento e cujas opções podem, por vezes, representar verdadeiras catástrofes em alguns acervos. É um convite à reflexão e à pesquisa.

\section{Fotografias}

Os acervos fotográficos brasileiros são compostos, em sua maioria, por fotografias produzidas com tecnologia predominante na segunda metade do século $\mathrm{XX}$, as chamadas gelatinas. Entretanto, no Brasil, também se formaram acervos compostos por material em albumina, negativos de vidro, alguns raros daguerreótipos, fotografias em cores, muitos diapositivos e mais recentemente, fotografias digitais.

Tal multiplicidade de processos, suportes e formatos será abordada nesta parte, bem como as principais causas de deterioração dos materiais fotográficos e seu tratamento para preservação.

\subsection{Processo fotográficos históricos}

Quando se observa uma fotografia convencional - ou tradicional -, é fácil perceber que o papel emulsionado (suporte) e o conteúdo informacional (imagem formada por meio de processos físicos, químicos e ópticos) que a compõem são inseparáveis. No caso das fotografias digitais, o suporte (magnético ou óptico) é uma parte física separada do conteúdo.

Essa é uma característica realmente diferenciadora da imagem digital que, ao contrário das fotografias convencionais, não tem no suporte um elemento significativo, mas um mero carregador físico. Como uma das consequências, temos que, a cada reprodução de uma imagem digital, o único elemento que muda é o suporte: o novo documento continua sendo idêntico ao que foi reproduzido.Este é um dos dados que confirmam, ou melhor, que explicam a mudança drástica da relação documento/suporte/informação consequente da revolução informacional que conduziu os arquivos à era pós-custodial e os trouxe à era eletrônica - documento era, até então, um registro de informação sobre um suporte material.

A histórica noção de suporte sofreu algumas alterações com a chegada do virtual. Os acervos que contêm fotografias passaram a contar com mais uma preocupação em termos da conservação dos suportes: as novas formas de se preservar a fotografia em meio digital, que rapidamente passou a fazer parte do conjunto de documentos produzidos e adquiridos pelas instituições.

Todavia, nos arquivos históricos o destaque continua a ser a fotografia emulsionada, já que a maior parte da massa documental que adquiriu o caráter de permanente é composta por materiais fotográficos tradicionais. E ela já conta com algumas variáveis, como o positivo 
(em papel), o negativo (em vidro ou em película) e o diapositivo (em película ou, mais raro, em vidro).

Outra realidade em curso é que em breve os processos de produção de imagens fotográficas, que até então eram atuais, modernos e praticados diariamente (papel e filme emulsionados com gelatina e sensibilizados por meio da abertura do diafragma da câmera fotográfica. Por esses motivos, será cada vez mais importante que os profissionais que lidam com tais acervos aprendam métodos e técnicas para a conservação do suporte fotográfico.

Fotografia é a impressão de imagens sobre um suporte sensível, por meio da ação da luz. Os suportes mais comumente conhecidos são o vidro, o papel ou as películas (filmes). Tais suportes são previamente emulsionados, ou seja, são revestidos por uma camada composta por uma substância aderente, o ligante, que pode ser gelatina, por exemplo, e por cristais (halogenetos) de prata (substâncias químicas sensíveis à luz).

No processamento tradicional, quando a camada fotossensível é exposta à luz, os cristais transformam-se em prata metálica preta. Após uma sucessão de banhos químicos (revelador, interruptor, fixador e água corrente), que é a revelação completa, é possível visualizar, finalmente, a imagem fotográfica formada pelos grãos de prata.

O primeiro a produzir uma imagem por meio da ação da luz foi o francês Joseph Nicéphore Niépce, em 1825. Tratava-se da vista descortinada de seu sótão, obtida por um processo heliográfico, inadequado para as reproduções comuns.

O nome que figura como inventor da fotografia, porém, é o de Louis Jacques Mandé Daguerre. Em $1837^{2}$, guardou em um armário uma placa sensibilizada com iodeto de prata. No dia seguinte, ao pegá-la, obteve uma imagem revelada. Esse processo de obtenção de imagem ficou conhecido como daguerreotipia.

O terceiro pioneiro de importância para o início da fotografia foi o inglês William Henry Fox Talbot, que inventou o negativo e o princípio das cópias múltiplas (1833). O processo de Talbot era chamado de photogenic drawings, ficando conhecido posteriormente como calotipia ou talbotipia.

Há ainda o francês Hercules Florence, que viveu no Brasil (chegou em 1824) e cunhou o termo fotografia em 1832. Em 1833, ele descobriu um método para produzir imagens com papéis sensibilizados com nitrato de prata e fixados com urina.

De lá para cá, aconteceram novas descobertas que só vieram melhorar ou acrescentar técnicas. Nessa linha evolutiva, desenvolveram-se também os principais processos fotográficos históricos, como detalhado a seguir.

\footnotetext{
${ }^{2}$ Em 1829, Niépce e Daguerre haviam se reunido para formar uma sociedade para o desenvolvimento da fotografia.
} 
A estrutura básica dos materiais fotográficos processados se assemelha ao esquema contido na figura 1.

Figura 1 Estrutura básica dos materiais fotográficos

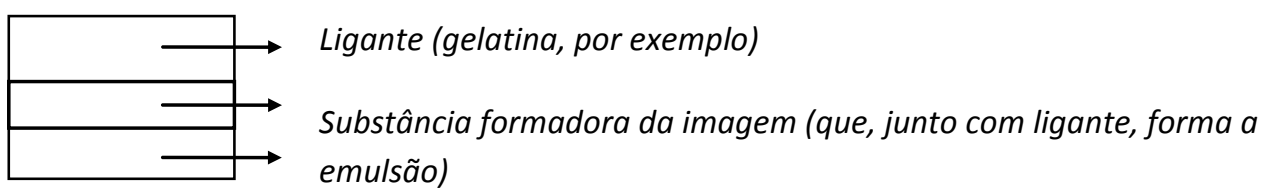

Fonte: a autora.

O daguerreótipo (1839) é uma imagem positiva e única, conforme ilustrado na figura 2. Apresenta-se espelhado, brilhante, guardado em estojos (de veludo, camurça, couro etc.); a informação encontra-se no amálgama e pode ser removida ao ser manipulada; é resistente à luz. É colorizado com aderência através de goma arábica e vapor (sopro) úmido.

Figura 20 daguerreótipo

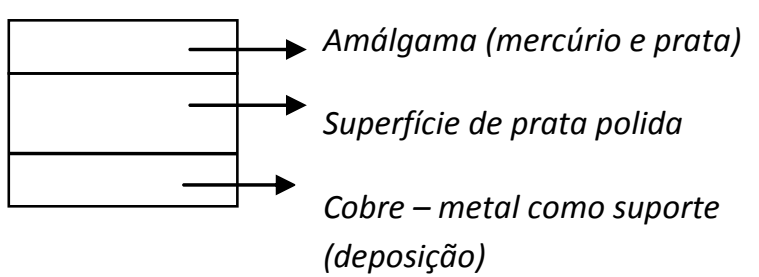

Fonte: a autora.

O ambrótipo ou positivo de colódio (1852) é "primo" do daguerreótipo; seu nome vem do grego ambros, que significa imortal; tem o colódio como ligante, a prata como substância formadora da imagem e o vidro como suporte, conforme a figura 3. O nitrato de celulose apresenta-se diluído.

Figura 3 Ambrótipo ou positivo de colódio

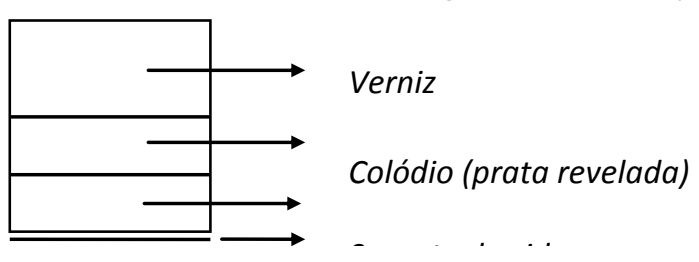

Fonte: a autora.

O ferrótipo (1856), conforme a figura 4, é também parente do daguerreótipo. Há, nele, uma predominância do preto. 
Figura 4 Ferrótipo

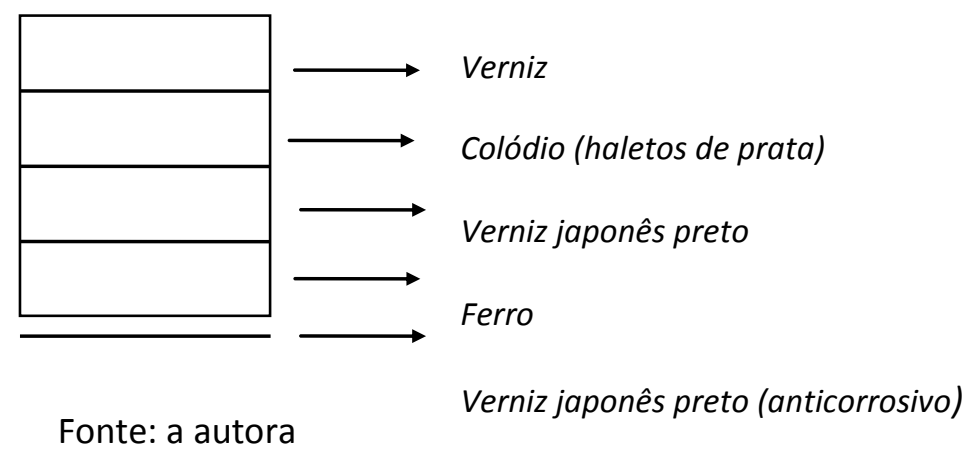

Os Photogenic Drawings (1833) são calótipos de papel salinizado de Talbot; sem ligante (a conservação será, por isso, diferente); papel sensibilizado, exposto e revelado.

Figura 5 Photogenic Drawings

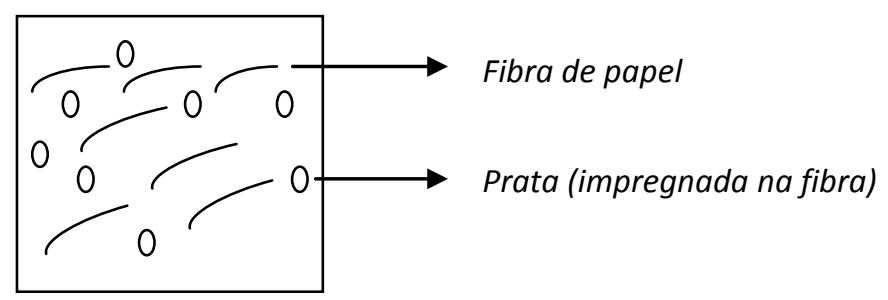

Fonte: a autora.

O albúmen (1848) apareceu na segunda metade do século XIX e se tornou o grande produto do período (obtido da clara de ovo, conforme a figura 6 . Muito encontrado no formato carte-de-visite ${ }^{3}$.

Figura 6 O Albúmen

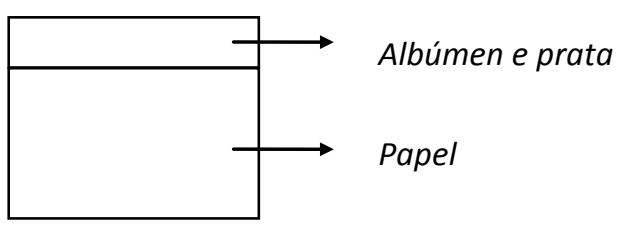

Fonte: a autora.

No colódio (1851), conforme a figura 7, a camada de barita isola o papel e proporciona melhor obtenção da imagem. A barita (sulfato de bário) é branca e aparece sob o colódio raspado.

\footnotetext{
${ }^{3}$ Ver exemplo: Carte-de-visite (frente e verso) de Lambert Partington, fotógrafo, Southport. Disponível em: <http://www.ephemera-society.org.uk/articles/articles.html>. Acesso em: 07 dez. 2015.
} 
Figura 7 Colódio

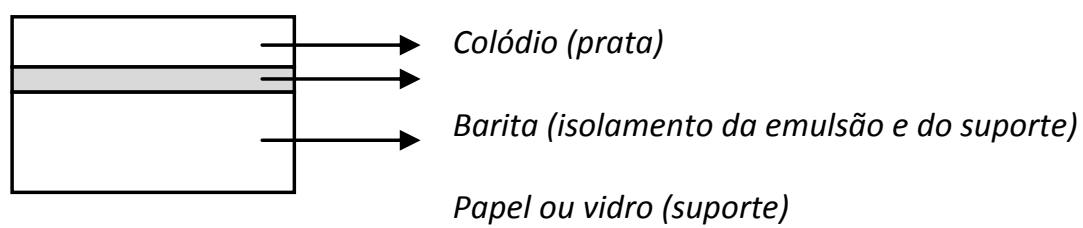

Fonte: a autora.

Processo tradicional, ainda em voga comercialmente, mas cada vez mais dando espaço a passos largos à fotografia digital, conforme contido na figura 8.

Figura 8 Processo tradicional

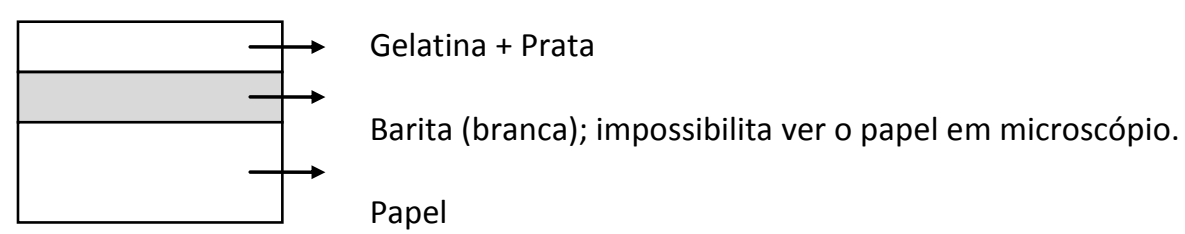

Fonte: a autora.

Recapitulando, as bases ou suportes de metal são encontrados no daguerreótipo e no ferrótipo e as de papel, no albúmen e no colódio e as de vidro, no ambrótipo.

Os principais ligantes são a albumina (derivada da clara de ovo), a gelatina (retirada de ossos e da pele de animais, geralmente dos bovinos) e colódio (diluição de nitrato de celulose em éter e álcool).

As bases plásticas ou flexíveis existem desde 1878, a partir da descoberta do nitrato de celulose (filme autocomburente). A evolução destas bases se deu com a descoberta do acetato de celulose na década de 1930 (safety film ou filme de segurança). Em seguida vieram o diacetato de celulose, o triacetato e o poliéster (os dois últimos a partir de 1960). O quadro 1 apresenta uma síntese desses processos.

Quadro 1 - Síntese dos principais processos fotográficos

\begin{tabular}{|c|c|c|c|}
\hline Suporte & Substância Fomadora da & Ligante & Nome do Processo \\
\hline
\end{tabular}




\begin{tabular}{|c|c|c|c|}
\hline & Imagem & & \\
\hline Cobre & Prata polida & Mercúrio/Prata & Daguerreótipo \\
\hline Vidro & Colódio & Verniz & Ambrótipo \\
\hline Ferro & Colódio & Verniz & Ferrótipo \\
\hline Papel & Prata & Não há & Photogenic Drawings \\
\hline Papel & Prata & Albumina & Albúmen \\
\hline Papel & Colódio/Prata & Barita & Colódio \\
\hline
\end{tabular}

Fonte: Miriam Paula Manini - Anotações durante Oficina de Conservação e Preservação de Fotografias (FUNARTE, Rio de Janeiro, 1994).

\subsection{Principais causas de deterioração}

A partir dessas informações será mais fácil compreender quais são - e por que - os principais fatores de deterioração dos materiais fotográficos.

\subsubsection{Causas extrínsecas}

\section{Umidade}

Pode-se citar como a primeira delas a umidade. O Brasil é, por assim dizer, um expert em umidade. Os acervos fotográficos brasileiros veem fungos e outros microorganismos proliferarem por causa desse item abundante, causado pelas características climáticas do nosso país.

O grande perigo da umidade é que tanto ela quanto os fungos (que podem causar danos irreversíveis) são, até certo ponto, invisíveis, justamente em suas piores fases: o ataque e a proliferação; por isto existe a necessidade de ações preventivas relacionadas ao acondicionamento, à guarda e à climatização.

Não há grande possibilidade de aparecimento de fungos nas albuminas como há nas gelatinas; as albuminas, por sua vez, costumam apresentar manchas conhecidas como foxing.

Os índices de umidade brasileiros podem superar os $90 \%$ em algumas regiões, durante alguns períodos do ano, enquanto um acervo de fotografias em preto-e-branco exige umidade relativa entre 30 e $50 \%$. 
A variação da umidade - e da temperatura - pode conduzir à alteração física do objeto fotográfico, bem como a outras reações químicas de deterioração e à atração de fungos e insetos. A umidade relativa acima de 50\% favorece o aparecimento e a proliferação de fungos, que mancham a imagem (as gelatinas ficam manchadas de forma irreversível) e a tornam solúvel em água (a gelatina amolece e pode ser dissolvida quando tratada com solventes ou mesmo com soluções aquosas).

Outros fatores que colaboram para o surgimento e sobrevivência dos fungos são o baixo nível de ventilação da área de guarda, a baixa incidência de luz e a presença de substratos que favoreçam a proliferação (os esporos precisam de superfícies nutrientes), como é o caso das emulsões de gelatina.

É necessário aliar a observação da umidade à avaliação da temperatura. As altas temperaturas - outra característica climática brasileira - são prejudiciais aos materiais fotográficos (compostos de substâncias, como se viu, muito instáveis). Quando combinado com alta taxa de umidade relativa do ar, o calor pode trazer ainda mais danos a um acervo fotográfico. As baixas temperaturas, por sua vez, aumentam a umidade relativa.

Vale citar a particularidade dos materiais à base de nitrato de celulose e sua autocombustão: alta temperatura somada com a característica autocomburente do nitrato pode causar incêndio.

Umidade e temperatura descontroladas podem alterar a forma - e até o conteúdo dos materiais fotográficos. Por exemplos, pequenas linhas rendilhando a imagem (principalmente as albuminas).

A oscilação grande ou brusca de temperatura também precisa ser evitada (principalmente quando há transporte de materiais de um ambiente mais fresco para um mais aquecido). As moléculas esgarçam-se quando há contração e retração, provocando alterações físicas nos materiais fotográficos, especialmente os de base em papel.

\section{Poluentes ambientais}

Fotografias expostas diretamente à ação de poluentes ambientais retêm sujidades naturais como a poeira do ar e excrementos de insetos, ambos carregados de materiais abrasivos. Por vezes pode ser encontrada uma ou outra imagem que foi deslocada de algum suporte ou de uma parede, trazendo no seu verso pedaços de papel, de tinta, de cimento e reboco.

Ambientes muito abertos, com corredores de ar, próximos de autoestradas ou de ruas movimentadas, perto de construções ou fábricas, em ambientes com pintura fresca, inseticidas, produtos químicos para limpeza: tudo isso, isolado ou reunido, pode ser muito 
prejudicial a um acervo. Os gases poluentes provocam umidade, que favorece o aparecimento de fungos e o amolecimento das gelatinas e assim por diante.

Luz

A luz, elemento essencial na formação da imagem fotográfica, pode, em alguma medida, ser prejudicial. Assim como nossa pele fica bronzeada quando exposta à luz solar ou como o jornal que escurece quando esquecido em qualquer canto, as fotografias podem sofrer alterações físicas e/ou visuais se expostas à iluminação intensa ou frequente. As albuminas são as maiores vítimas da luz, esmaecendo à menor exposição; por isto, em exposições de originais fotográficos é habitual que se observe a iluminação indireta aplicada sobre as imagens.

Acervos guardados em ambientes repletos de janelas ou que contêm luzes inadequadas podem ter suas fotografias afetadas.

A radiação ultravioleta está tão presente nas lâmpadas fluorescentes quanto na luz natural. As lâmpadas incandescentes ou de tungstênio, por sua vez, aumentam consideravelmente o calor na área de guarda. Deve-se evitar exposição prolongada à luz, radiação ultravioleta, lâmpada fluorescente, luz do sol e lâmpada incandescente.

Insetos

Quanto aos insetos, formigas, traças, cupins, brocas e baratas são os mais comuns encontrados em acervos; são também mais interessados em fotografias que os roedores. Todos eles podem causar danos irreparáveis nos materiais fotográficos, tais como manchas, resíduos de excrementos, furos, perda de suporte e/ou da emulsão.

Os ligantes, como vimos, são feitos com gema de ovo (albumina) e gelatina; tais substâncias, principalmente se submetidas a altas temperaturas e a altos índices de umidade, podem tornar-se muito atraentes para os insetos. O próprio fungo que prolifera em documentos mal guardados pode atraí-los.

\section{Processamento inadequado}

O processamento inadequado no momento de se produzir uma fotografia também pode afetar sua conservação. O primeiro cuidado é efetuar o processamento com higiene e seguindo padrões técnicos de banhos e de lavagem dos filmes e das fotografias. Um problema que pode ocorrer é a não remoção de tiossulfato de sódio (fixador) e de complexos de prata e tiossulfato, devido à falta de monitoração das etapas de fixação e lavagem. 
Quando se encontram imagens com manchas em um tom amarelo escuro, quase marrom, isto é um sinal de que foram utilizados químicos fotográficos já vencidos ou utilizados à exaustão.

As viragens ${ }^{4}$ (em ouro, selênio, platina, enxofre etc.) também contribuem para a preservação da fotografia (especialmente a viragem em platina), além do processamento fotográfico para permanência.

\section{Acondicionamento}

Existem, também, problemas de acondicionamento: fotografias coladas em papéis com alto índice de acidez podem conter duplo "veneno": não só o papel é portador de acidez, mas também o adesivo. Papel cristal e papel manteiga, por exemplo, são contraindicados.

Papéis que não são livres de acidez e colas também ácidas podem ter suas substâncias migradas para a fotografia, oxidando-as e provocando, por vezes, o aparecimento de manchas.

Os adesivos são, geralmente, ácidos e higroscópicos e, por isso, provocam o esmaecimento da imagem fotográfica. Papéis de entrefolhamento, pastas e caixas confeccionados com material contendo acidez também são altamente prejudiciais. Tais materiais acessórios também devem ser livres de lignina, enxofre, adesivos e plastificantes.

Hastes de metal de pastas suspensas e bordas de reforço também de metal encontradas em algumas caixas não só podem oxidar (= enferrujar) como também riscar as imagens (no manuseio inadequado). Anotações em papel de entrefolhamento, quando feitas com caneta (principalmente hidrocor), podem ter sua tinta migrada para a fotografia, comprometendo seu estado de conservação.

Caixas de camisa ou de calçados reutilizadas, abarrotadas de fotografias, de dimensão e cromia variadas representam descuido total. Fotografias grandes em invólucros pequenos causam dobraduras, manchas, rasgos e até mesmo perda de suporte e da informação fotográfica.

A guarda está diretamente relacionada com o local escolhido e com o tipo de mobiliário utilizado. Alguns dos principais problemas estão na oxidação (aparecimento de ferrugem) de armários metálicos e na liberação de gases que a pintura dos móveis pode provocar.

Materiais fotográficos só podem ser guardados em mobiliário de madeira se esta for previamente tratada (para evitar ataque e proliferação de cupins), se a área de guarda for climatizada e receber monitoramento ambiental.

\footnotetext{
${ }^{4}$ Tipo de banho adicional que pode ser aplicado com vistas à preservação.
} 
A madeira (compensados, aglomerados e também as caixas de cartão corrugado) é um elemento instável, muito suscetível a alterações por causa da umidade: os armários absorvemna do ar, sofrendo inchaço e, depois, podem expelir esta umidade nos materiais guardados em seu interior. Outras desvantagens da madeira: atraem insetos, liberam gases e há um tipo de fungo que se desenvolve especialmente na madeira.

Acervos com fotografias de grande formato (maiores que 18 por $24 \mathrm{~cm}$ ou que 25 por $30 \mathrm{~cm}$ ) devem contemplar em sua área de guarda algumas mapotecas para contenção de itens de grandes dimensões.

Mobiliário de metal é sempre o mais adequado, pois, em condições climáticas adversas, protege melhor os documentos. Entretanto, ao menor sinal de oxidação (ferrugem), deve ser descartado. $O$ ideal é o mobiliário de aço com pintura polimerizada em fornos de alta temperatura (este é o procedimento normal de acabamento em móveis de aço de boa qualidade).

Em suma, os materiais problemáticos são os seguintes:

a. madeira (óleos, resinas etc.): precisa ser tratada (quando lavada pela água da chuva, nela só permanecem a celulose e a lignina); é necessário que a madeira tenha um tempo de cura para que libere o máximo de substâncias; o aroma é outro problema, pois o ambiente de acervo deve ser inodoro; substâncias interagem com o acervo e é necessário saber a origem da madeira;

b. Revestimentos de parede (fórmicas, duraplac etc.): são melamínicos; o maior problema está nos adesivos desses materiais; o melhor revestimento é o verniz poliuretano;

c. Concreto: na reação com a água libera vapores alcalinos muito danosos aos materiais fotográficos; é preciso também dar a ele um tempo de cura (no mínimo 30 dias ou até desaparecer o cheiro de cimento fresco).

d. Um prédio inadequado possui: eletrificação interna; acúmulo de água na parte superior; incidência de infravermelho e ultravioleta; passagem subterrânea de lençol freático. Um prédio adequado, por sua vez, deve contemplar: paredes isolantes ou duplas; ar circulante filtrado; fornos que permitam isolamento solar e de água; construção de, no máximo, três andares; aberturas proporcionando aeração e luminosidade em casos de pane no sistema elétrico; depósitos sem aberturas; isolamento térmico; isolamento da umidade; isolamento da luz. A ordenação ideal da 
localização das áreas do prédio é a seguinte, da parte mais externa para a mais interna: atendimento ao público; área de trabalho; salas de armazenamento.

\section{Vandalismo e tratamento inadequado}

A diferença entre vandalismo e tratamento inadequado está em que o primeiro acontece provocado por uma intenção e o segundo pode ser fruto da ignorância. $O$ tratamento inadequado acontece quando há ignorância em como tratar fotografias de forma ideal; não se deve descartar também o descaso e o desinteresse.

Adesivos (colas), clipes, grampos e hastes metálicas; elásticos e plásticos não porosos, tintas e lápis inadequados: nada disto deve ser aplicado na identificação, acondicionamento e guarda de fotografias.

Outros problemas: manusear as fotografias sem luvas e - mais grave - com as mãos sujas ou impregnadas de cremes ou outros cosméticos; guardar fotografias em invólucros, pastas ou caixas menores que as próprias fotografias; fumar na área de tratamento ou de guarda; higienizar fotografias em local afetado por corrente de ar ou com janelas abertas; alimentar-se ou carregar líquidos (café, água etc.) na área de tratamento ou guarda, entre outros.

Deve-se sempre pegar os objetos com as duas mãos, nunca os empilhar nem forçar a separação de materiais aderidos um ao outro.

\section{Sinistros}

Sinistros acontecem, sejam causados por fenômenos da natureza ou por falha humana. Incêndios e inundações são os acidentes mais comuns, sendo os primeiros os de consequência mais grave.

Fotografias afetadas pelo fogo são irrecuperáveis; a água, embora altere gravemente documentos fotográficos, provoca danos menos sérios. Na verdade, as sujidades que as inundações carregam - terra, madeira, excrementos de animais, folhas, substâncias desconhecidas etc. - é que trazem os maiores prejuízos.

Uma solução de precaução é guardar os documentos o mais longe possível do chão (evitar pavimentos térreos, sótãos, sanitários e porões), além de manter limpos o telhado, as calhas e o encanamento do prédio. Soluções de mobiliário podem proteger melhor as fotografias desses acidentes; prédios equipados com detector de fumaça e sprinkler também são recomendados. 
É bom manter as instalações elétricas em constante supervisão, além de definir equipe para ligar e desligar equipamentos diariamente (inclusive o ar condicionado, quando o acervo não possuir vigilância noturna) e para desligá-los da tomada nos feriados, finais de semana e durante tempestades (caso não haja instalação de segurança do tipo disjuntor e/ou para-raios nas redondezas).

Outra precaução é ter um telefone de fácil acesso próximo ao acervo, com o número do corpo de bombeiros e dos responsáveis pela instituição.

Incêndios e inundações causados de forma premeditada são exemplos de vandalismo. Há também atitudes menos graves, mas que contribuem igualmente para promover ou acelerar a deterioração: escrever na frente da fotografia (diretamente na imagem) ou no verso (com caneta, principalmente hidrocor), rasgar fotografias (com perda de informação, principalmente), grampeá-las ou as prender com clipes metálicos (ou mesmo de plástico, especialmente os não lisos), manuseá-las com descuido provocando amassados e dobras, apoiar sobre a imagem objetos cortantes ou pesados.

Escrever na imagem é danoso na certa, pois as tintas de canetas não são livres de acidez; escrever no verso é menos grave, porém, com o tempo, a tinta passa por um processo de migração e chega à imagem, provocando sua deterioração.

Grampos e clipes metálicos, além de imprimir sulcos e provocar furos na fotografia, podem sofrer oxidação e afetar o documento com ferrugem.

Além dos fatores externos, há um conjunto de causas intrínsecas de deterioração de materiais fotográficos, explanadas a seguir.

\subsubsection{Causas intrínsecas}

Vidro

O uso do negativo de vidro predominou da década de 1850 à de 1880 . O vidro possui a causa de deterioração intrínseca mais evidente: é quebrável. Portanto, é necessário cuidado especial no manuseio. Negativos de vidro quebrados e/ou trincados, entretanto, podem ser reintegrados (desde que existam todos os pedaços).

Aconselha-se também a duplicação dos negativos de vidro através de procedimento químico (utilização de rebaixador: fotografa-se um negativo de vidro e, na revelação, usa-se o rebaixador para que as partes escuras continuem escuras e as partes claras continuem claras no novo negativo, agora flexível).

Nitrato de celulose 
Graças ao surgimento do nitrato de celulose, na segunda metade do século XIX, o cinema e a indústria cinematográfica se desenvolveram tal como os conhecemos antes do advento da eletrônica e da informática (o mesmo vale para os filmes de raios-X e a aerofotogrametria).

Material dos mais instáveis, os negativos em base de nitrato de celulose, quando submetidos a altas temperaturas, podem sofrer combustão espontânea. O aumento de temperatura pode fazer com que as bases de nitrato passem por uma autocombustão ${ }^{5}$, o que representa um risco não só ao próprio material como para todo o acervo. Além disso, os gases que emanam da decomposição do nitrato são altamente prejudiciais aos outros materiais guardados na mesma área.

Por causa dessas características, é aconselhável que os materiais em nitrato sejam guardados em área restrita, climatizada, isolada do restante do acervo e protegida com porta corta-fogo. Recomenda-se, também, a reprodução em material contemporâneo com vistas à preservação da informação no caso de destruição total.

A partir do início do século XX, o nitrato passa a ser gradualmente substituído por uma base flexível de acetato de celulose (o filme de segurança ou safety film, como se pode ler nas bordas de alguns negativos).

Existem maneiras de identificar a ocorrência de nitrato de celulose dentro de um acervo. Pode-se, por exemplo, verificar se o material é um nitrato acompanhando suas fases de deterioração:

- amarelecimento uniforme e esmaecimento simultâneo da imagem;

- aderência da emulsão a outros filmes e/ou a invólucros de acondicionamento, acompanhada de liberação de forte odor de ácido nítrico;

- $\quad$ amolecimento da base, produção de bolhas e perda de consistência do filme;

- decomposição final em um pó marrom.

Entretanto, em vez de se assistir a esse verdadeiro "filme de terror", pode-se fazer um teste de flutuação. Se uma pequena amostra de filme, ao ser mergulhada em um recipiente com tricloretileno ${ }^{6}$, afundar, trata-se de nitrato; se flutuar, é um filme de segurança. Assim, ao

\footnotetext{
${ }^{5}$ No filme Cinema Paradiso (Itália, 1989), de Giuseppe Tornatore, há uma sequência em que pequenos pedaços de película, enrolados, guardados debaixo da cama de um garoto, provocam um pequeno incêndio. Da mesma forma, o recente "Bastardos inglórios" (EUA, 2009), de Quentin Tarantino, mostra o filme de nitrato utilizado como combustível poderoso.

${ }^{6} \mathrm{O}$ tricloretileno (assim como o tricloroetano) é um produto altamente tóxico; portanto, tal teste deve ser feito em local ventilado ou em capela apropriada, com proteção física (luvas, máscara e óculos).
} 
identificá-lo, a melhor atitude é providenciar sua duplicação, gerando negativos em base de gelatina ou procedendo à sua digitalização.

\section{Diacetato de celulose}

As bases plásticas ou flexíveis existem desde a descoberta do nitrato de celulose. 0 diacetato de celulose foi a primeira tentativa da então indústria fotográfica para resolver o problema do nitrato.

A base de diacetato de celulose é, porém, instável a ponto de haver alteração nas dimensões do negativo (nas bordas perfuradas, especialmente), podendo a emulsão descolarse do suporte flexível. A retração da camada de emulsão sobre o suporte provoca o que se chama de craqueler $^{7}$ : o diacetato enruga, passa pelo craqueler e se quebra. Além disso, durante seu processo de deterioração, libera gases que podem prejudicar, também, outros materiais fotográficos guardados no mesmo local. Tais alterações físicas podem ser promovidas e/ou agravadas pelo descontrole da temperatura e da umidade relativa.

Os negativos flexíveis em diacetato, ao se apresentarem enrugados, podem ser acondicionados em caixas/pastas de papel especial, onde podem ser colocados delicadamente, de modo que o contato entre eles e a caixa/pasta mantenha certa frouxidão.

Cada uma dessas evoluções e cada um dos processos abordados anteriormente forneceram consequências aos métodos e técnicas de conservação de fotografias, relativamente aos seus variados tipos de suporte. Entretanto, a mesma importância deve ser dada ao tratamento da informação contida nas imagens fotográficas.

\section{Diagnóstico de acervo}

A ideia de diagnóstico que aqui se apresenta inclui muito mais o aspecto da conservação e da preservação dos suportes documentais do que o conteúdo informacional da imagem, ainda que este seja igualmente importante.

Há algumas perguntas fundamentais que se pode fazer ao acervo:

a. Quais os processos fotográficos existentes no conjunto de fotografias?

b. Qual a quantidade de fotografias por processo?

c. Qual a quantidade de negativos flexíveis e de vidro?

d. Existe processamento em cores no conjunto fotográfico?

\footnotetext{
${ }^{7}$ Na verdade, a tradução de craqueler ("dar à porcelana um esmalte salpicado") não corresponde ao efeito que se deseja denominar. O mais correto seria craquelure ("fenda no verniz e na tinta") ou craquer ("estalar, rachar-se"). A bem da verdade, o que acontece é que a imagem fica com um aspecto trincado, rendilhado.
} 
e. Há materiais em acetato e em nitrato de celulose?

f. Qual a quantidade de fotografias por dimensão; e por cromia?

g. O material sofreu algum sinistro, vandalismo ou maus tratos?

h. As fotografias estiveram acondicionadas e/ou guardadas de forma inadequada desde que foram produzidas?

i. A região de guarda do material possuía clima de que tipo? Era litorânea, próxima à vegetação densa, próxima a curso de água?

j. Qual o perfil do usuário das imagens e com qual frequência visita o acervo?

O diagnóstico deve ser feito segundo os processos fotográficos históricos, as características físicas dos materiais fotográficos, o histórico do material (como e onde foi gerado, como e onde esteve guardado) e a situação dos mesmos com relação à deterioração (por causas intrínsecas ou extrínsecas).

Higienização

a. Base de papel

A higienização de fotografias (positivos, ampliações ou cópias) pode ser mecânica ou química. Na realidade, todos os documentos fotográficos devem passar pela higienização mecânica, que se inicia pela retirada de clipes e grampos metálicos; pela remoção de resíduos visíveis a olho nu, como excrementos de insetos, pedaços de elástico, de papel, de tinta e reboco de parede (geralmente colados no verso); pela retirada de bases de suporte em papel ácido.

Nessa fase são utilizados os seguintes instrumentos: luvas brancas de helanca ou de algodão ${ }^{8}$, pinças e espátulas metálicas (odontológicas), espátula de osso, pincel soprador e lente de magnificação ou lupa.

Ainda como parte da higienização mecânica, é realizada a varredura da imagem e do verso da fotografia. Nesse momento devem ser usados: pincel macio, de pelagem especial, para a imagem, e trinchas ou pincéis comuns para o verso.

Se o verso de uma fotografia estiver pleno de sujidades (marcas do tempo, de guarda inadequada etc.), pode ser feita uma higienização mecânica com pó de borracha branca de

\footnotetext{
${ }^{8}$ Uma solução de baixo custo é a confecção de luvas de algodão feitas a partir de camisetas brancas usadas que podem ser doadas por funcionários e usuários do acervo.
} 
plástico. O pó deve ser aplicado com algodão hidrófilo ou com uma boneca ${ }^{9}$ através de movimentos giratórios (sempre no mesmo sentido: horário ou anti-horário); depois disto, o verso da fotografia deve ser novamente varrido.

A higienização química envolve substâncias como álcool etílico e solvente; ela é mais especializada e requer muitos cuidados, pois é prejudicial à saúde e ao material a ser tratado. Nessa fase, utilizam-se, além de algodão hidrófilo, palitos de madeira e pedaços de papel neutro.

b. Base flexível

Pode-se realizar a limpeza mecânica de bases flexíveis (diapositivos, negativos, películas cinematográficas, microfilmes, microfichas, radiografias etc.) com tecido de algodão branco antiestático. Antes de iniciar a higienização é necessário distinguir qual a face plástica e qual a face da emulsão, sendo que a última exige cuidados maiores devido à sua fragilidade.

Essas bases, quando atacadas por fungos, trazem manchas, muitas vezes, impossíveis de serem removidas. Pode-se tentar limpar a face plástica com hastes flexíveis com extremidades recobertas de algodão embebido em tricloretileno (ou tricloroetano), sempre lembrando de ter cuidado com o nível de toxidade dessas substâncias.

Para a higienização de filmes cinematográficos, é essencial o uso de moviola para auxiliar na bobinagem e rebobinagem. Além do uso mecânico, a moviola será útil também na verificação de sujidades, fungos e outros detalhes presentes na película através do uso de seu visor.

\section{c. Base de vidro}

Os negativos de vidro obedecem a regras semelhantes às bases flexíveis. Pode-se realizar sua limpeza mecânica com algodão. Antes de iniciar a higienização, é necessário distinguir qual a face de vidro (mais brilhante) e qual a face da emulsão (mais fosca), sendo que a última exige cuidados maiores.

O vidro, quando atacado por fungos, traz manchas, muitas vezes, impossíveis de serem removidas. Pode-se tentar limpar a face de vidro com hastes flexíveis com extremidades recobertas de algodão embebido em uma mistura de uma parte de álcool para duas partes de água destilada. $\mathrm{O}$ álcool, além de auxiliar na remoção de sujeira, promove rápida evaporação por sua alta volatilidade, minimizando a ação umidificadora desse tipo de higienização.

\footnotetext{
${ }^{9}$ Boneca (ou peteca) é um instrumento fácil de confeccionar: deve-se envolver um chumaço de algodão hidrófilo em um tecido branco, também de algodão, e prender com barbante ou fita crepe. 0 instrumento fica com o aspecto de uma boneca de pano ou de uma peteca. Ele é usado para esparramar o pó de borracha na superfície a ser limpa.
} 
Acondicionamento e guarda

Esta parte se refere aos invólucros, jaquetas, sacos, pastas, caixas, gavetas, armários, mapotecas, salas, pisos, prédios e locais, bem como ao uso de equipamentos de climatização e de monitoramento de temperatura e umidade relativa.

\section{a) Soluções de acondicionamento}

Durante muito tempo, as instituições que se preocuparam em acondicionar adequadamente sua documentação fotográfica utilizaram invólucros de polietileno.

Esse material, domesticamente conhecido como aquele saco plástico que envolve discos de vinil, tem certa porosidade, ao mesmo tempo em que protege da poeira.

Um grande inconveniente dos invólucros de polietileno é que ele tinha, muitas vezes, que ser fabricado dentro da própria instituição (com o uso de seladora de alimentos, um entre vários eletrodomésticos levado para o laboratório de preservação), o que sempre demandou mão de obra e tempo de trabalho.

Menos utilizado - antigamente - que o polietileno era o poliéster, que também precisou, por algum tempo, ser manipulado (cortado e vincado) para que se fabricassem jaquetas ou envelopes.

As vantagens do invólucro de poliéster sobre o de polietileno são:

- não necessita de máquina para ser confeccionado (a seladora, no caso, torna-se dispensável);

- poliéster é mais translúcido, possibilitando melhor visualização da fotografia;

- sua composição o torna mais resistente, o que acaba por proteger melhor o documento fotográfico.

Atualmente, já existe um fabricante no Brasil produzindo em escala industrial todo um conjunto de materiais para conservação de fotografias, no qual se incluem jaquetas de poliéster. Elas são fechadas por prensagem (como coadores de papel), possuem aberturas laterais e uma lâmina de papel neutro para entrefolhamento.

As fotografias são acondicionadas duas a duas, o verso ficando em contato com o papel neutro. A identificação da imagem pode ser feita nesse papel, com lápis macio (6B). Tanto os invólucros de polietileno quanto as jaquetas de poliéster são reunidas, 15 a 15, em pastas suspensas de papel neutro, com hastes e prendedores de plástico (o que significa um total de 30 fotografias por pasta). 
Outras soluções de acondicionamento para negativos de vidro e flexíveis, fotografias, álbuns e outros itens utilizam basicamente o papel neutro para sua confecção: envelopes, pastas, caixas etc.

Fotografias de grande formato (maiores que 20 por $25 \mathrm{~cm}$ ) devem ser acondicionadas em caixas (sempre com entrefolhamento), envelopes ou pastas especialmente confeccionadas.

b) Mobiliário

A guarda dos materiais fotográficos se refere, principalmente, aos móveis utilizados para se colocar as pastas, os envelopes e as caixas de acondicionamento.

Deve-se evitar ao máximo o uso de móveis de madeira, pois esse material, por ser hidrófilo, retém umidade, possibilitando a proliferação de fungos, além de liberar a própria umidade sobre os materiais neles guardados. No caso de utilizar móveis de madeira, eles devem receber tratamento especial na sua fabricação, de maneira a serem impermeabilizados e ficarem livres de ataques de cupins.

O ideal é que se utilizem armários, arquivos e mapotecas de aço. Com esse material, entretanto, é preciso que se tenha um cuidado frequente com a oxidação, pois a ferrugem pode, igualmente, afetar os materiais fotográficos. Outro cuidado a se tomar é com arestas e pontas de metal, que podem riscar materiais mal acondicionados. O ideal é utilizar armários com pintura eletrostática polimerizada em epóxi.

\section{c) Climatização e monitoramento ambiental}

O bom aproveitamento de um acondicionamento não muito ideal e de uma guarda pouco adequada pode ser obtido através da climatização.

A manutenção da temperatura e da umidade relativa ideais em uma área de guarda pode neutralizar a ação de fungos em papéis de acondicionamento que não sejam neutros ou que não sejam livres de acidez, a ação da oxidação em mobiliários de aço bem como a retenção da umidade em armários de madeira.

Além disso, é importante observar que o próprio documento fotográfico em preto-ebranco necessita de ambiente com temperatura entre 18 e $21^{\circ} \mathrm{C}\left(+\right.$ ou $\left.-2^{\circ} \mathrm{C}\right)$ e com umidade relativa de $50 \%$, para sua melhor preservação.

Os principais equipamentos de climatização são $\mathrm{o}$ ar condicionado e o desumidificador. O primeiro, mais conhecido, serve para deixar a temperatura da área de guarda no ponto desejado. O desumidificador, como o próprio nome diz, serve para retirar a umidade excedente do ambiente de guarda. 
A área climatizada, entretanto, precisa ser monitorada, ou seja, é preciso saber qual a temperatura e a umidade relativa do ar da área de guarda. Os principais equipamentos de termohigrógrafo monitoramento ambiental são o termohigrógrafo e o psicrômetro (de aspiração ou giratório).

O termohigrógrafo fornece a variação de temperatura e umidade relativa em determinado período de tempo ( 24 horas ou 7 dias) e o psicrômetro mede instantaneamente a temperatura e a umidade relativa em determinada área.

A combinação desses equipamentos com o ar condicionado e com o desumidificador deixará a área de guarda na temperatura e umidade relativa desejáveis constantemente.

\subsection{Outros itens fotográficos}

Esta parte tratará de materiais fotográficos diferentes da fotografia em preto-ebranco, com suporte de papel, chamada de cópia, positivo ou ampliação, já contemplada até o momento. Além dela existem as fotografias em cores, os diapositivos (ou slides), os negativos (de vidro e flexíveis), os álbuns fotográficos e as polaroides. A esses itens se aplicam todas as coisas vistas até agora, com algumas exceções. Vamos a elas.

\section{Fotografias coloridas (ou em cores)}

As origens da fotografia colorida datam da década de 1930, tendo alcançado seu pleno desenvolvimento na década de 1940.

Os principais problemas a serem apontados com relação à conservação de fotografias em cores se referem à temperatura necessária à sua área de guarda. Enquanto o material em preto-e-branco sobrevive bem em uma variação de 16 a $23^{\circ} \mathrm{C}$, as fotografias em cores exigem temperaturas que variam de -8 a $2^{\circ} \mathrm{C}$, condição impensável em boa parte dos acervos fotográficos brasileiros.

Tal exigência se deve à composição do material em cores; além dos sais de prata e do ligante, há pigmentos em sua formação que são muito sensíveis a altas temperaturas e à ação da luz que, se muito intensas, provocam esmaecimento da imagem até seu total desaparecimento (situação só possível em condições muito específicas de maus tratos e/ou catástrofes).

\section{Diapositivos (ou slides)}

Em 1946, a Kodak lança o filme positivo Ektacrome $F$ (diapositivo). É útil que se estabeleçam aqui as principais diferenças entre positivo fotográfico, negativo e diapositivo:

positivo: imagem positiva em papel; 
negativo: imagem negativa em base flexível ou de vidro;

diapositivo: imagem positiva em base flexível ou de vidro (a última mais rara).

O diapositivo é utilizado para projeção em tela ou parede apropriada, através de sua ampliação; requer, portanto, ao contrário da fotografia, um equipamento para ser visualizado. Há também os monóculos, largamente utilizados nos anos 1970, especialmente para lembranças comemorativas ${ }^{10}$.

Os filmes de diapositivos têm o mesmo aspecto dos rolos de filmes em cores e em preto-e-branco anteriormente utilizados. Após a exposição de cada fotograma, o filme é revelado como diapositivo. A fita toda do rolo é então picotada fotograma por fotograma, e cada um deles é montado em jaquetas ou molduras - ou, ainda, dentro do monóculo. Desta forma, a película fica protegida pela moldura, que deve ser de material resistente (plástico) e nunca de papel ou papelão ${ }^{11}$.

Sempre que se depara com um conjunto de diapositivos emoldurados com papel, deve-se transferi-los para molduras plásticas. Nessa transferência é importante que se transfiram também possíveis informações escritas na moldura de origem. As anotações devem ser feitas, de preferência, com lápis macio (6B).

É muito comum o ataque de fungos em diapositivos. Tanto estas placas de umidade quanto outras sujidades só são limpas com a utilização de substâncias altamente prejudiciais à saúde (cancerígenas): o tricloroetano ou o tricloretileno.

Sua manipulação deve ser feita com luvas e óculos, além da utilização de capela de exaustão. Deve-se trabalhar durante 30 minutos e parar por 20 minutos, para continuar o trabalho em seguida.

Muitas vezes o ataque de fungos é muito sério e as manchas provocadas são irremovíveis; o processo de proliferação dos micro-organismos, entretanto, é estacionável, principalmente se os materiais higienizados estiverem - ou passarem a ser - guardados em área climatizada.

Outro ponto a ser considerado é a forma de acondicionamento dos diapositivos. Em primeiro lugar, todos devem ser emoldurados, pois, além do uso (projeção) exigir a moldura, o manuseio torna-se mais seguro ${ }^{12}$.

\footnotetext{
${ }^{10}$ Ver exemplo em: <http://www.ahtrine.com.br/2008/05/08/momento-nostalgico-monoculos/>. Acesso em: 07 dez. 2015.

${ }^{11}$ Ver exemplo em: <http://www.oficinadopapel.com.br/index.php?route=product/product\&product_id=134>. Acesso em: 07 dez. 2015

${ }^{12}$ Ver exemplo de Projetor de Diapositivos Canaleta em: <http://professordigital.wordpress.com/2010/07/17/usopedagogico-de-apresentacoes-de-slides-digitais/>. Acesso em: 07 dez. 2015; e exemplo de Projetor de Diapositivos
} 
Podem-se acondicionar conjuntos de diapositivos em caixas plásticas apropriadas, desde que a área de guarda seja climatizada (com temperatura e umidade relativa recomendáveis para material em preto-e-branco ou em cores, conforme o caso).

Outra solução de acondicionamento são as cartelas de plástico suspensas, que funcionam por encaixe ${ }^{13}$.

Para o tratamento da informação - e também para visualizar o objeto fotográfico - é necessário que se tenha uma mesa de luz (negatoscópio) e também um projetor.

\section{Negativos}

O negativo, por definição, é uma imagem fotográfica reduzida e invertida: as partes escuras do negativo correspondem às partes claras do positivo e vice-versa. Ele é o original fotográfico e pode ser matriz de inúmeras fotografias, cópias ou ampliações. Sob esse aspecto, é aconselhável que se preserve, preferencialmente, o negativo, em detrimento da mesma imagem em positivo. Outro fator que concorre para essa decisão é que os negativos ocupam menos espaço, embora a pesquisa em material ampliado seja mais fácil e acessível (há também a presença quase constante de anotações de identificação no verso das fotografias em papel, o que não acontece no caso dos negativos).

A higienização obedece aos mesmos cuidados que os diapositivos. Já o acondicionamento é feito como o material em positivo.

\section{Álbuns fotográficos}

Os álbuns de fotografias são objetos muito comuns de aparecer nos acervos. A principal recomendação que se faz com relação a eles é que não sejam desmembrados, ou seja, deve-se manter as fotografias no álbum, coladas ou presas, na sua forma original.

Caso se perceba, através de um diagnóstico, que as fotografias estejam sofrendo muito com a ação do adesivo e com a ação do papel quase sempre ácido que serve de base onde se adere a foto, recomenda-se a reprodução das imagens, criando negativos de segunda geração ${ }^{14}$.

Outro problema comum é a presença de papéis de entrefolhamento inadequados, como o papel manteiga ou o de seda, geralmente já bastante amarelecidos. Pode-se optar por trocá-los por folhas de polietileno ou de poliéster, ou mesmo aplicar tais plásticos entre o papel de seda ou manteiga e a(s) fotografia(s).

Carrossel em: <http://www.museuhistoriconacional.com.br/images/galeria06/mh-g6a038.htm>. Acesso em: 07 dez. 2015.

${ }^{13}$ Ver exemplo em: <http://www.zornita.com.br/slides.php>. Acesso em: 07 dez. 2015.

${ }^{14}$ Quando se fotografa uma fotografia para dela obter uma nova matriz, o novo negativo é chamado de negativo de segunda geração. 
Problema mais sério surgiu no final da década de 1970/início da década de 1980: os álbuns de dupla aderência; a fotografia fica aderida na página do álbum e é coberta por uma película de plástico também revestida de cola, para manter a fotografia no lugar. A fotografia recheio de um sanduíche de adesivos - sofrerá a ação dessas colas tanto na frente quanto no verso, tendo seus dias contados (principalmente se não existirem seus negativos). A marca mais conhecida - Kassuga - fez furor entre o público doméstico, habituado a registrar acontecimentos da própria vida, as fotografias de família etc. O que é pior é que tais registros já eram, naquela época, em sua maioria, em cores, material de conservação mais difícil.

A higienização de um álbum deve ser feita interna (folhas) e externamente (capa), com o uso de pincéis e trinchas adequados.

O principal cuidado que se deve tomar é com a lombada da encadernação, principalmente se se tratar de material em couro, no qual é comum o ataque de brocas e traças (peixe prateado).

Depois de limpos, o ideal é que se acondicionem os álbuns em caixas de papel neutro especialmente confeccionadas, sob medida, para cada álbum. Tais caixas podem ser guardadas em prateleiras, em estantes de aço, ou em gavetas de mapotecas.

\section{Polaroide}

Em 1948, Edwin Land inventa o sistema Polaroid. A fotografia feita com máquina Polaroid é instantânea: sua revelação acontece automaticamente após a tomada e uma cópia é retirada imediatamente da câmera. Seus principais problemas são o esmaecimento fácil e inexistência de matriz em negativo. Esse tipo de fotografia parou de ser produzido nos anos 1980, mas sua câmera foi relançada em edição limitada no ano de 2010.

\section{Microformas}

Os microfilmes e as microfichas obedecem aos mesmos cuidados observados com os negativos flexíveis.

\section{Películas cinematográficas}

As películas recebem tratamento semelhante ao dos negativos flexíveis, diferenciandose pela extensão de suas fitas, enroladas em bobinas ou em botoques apropriados.

Quanto às suas dimensões ou bitolas, as películas podem ser de 8 (cinema doméstico), 16 (cinema amador) ou $35 \mathrm{~mm}$ (cinema profissional), sendo esta a medida da largura do filme.

Higienização 
Há dois tipos de higienização possível de se fazer em películas: mecânica e química. A higienização mecânica é feita com veludo de algodão branco, através da rolagem completa do filme em uma moviola. Deve-se ter o cuidado de usar luvas brancas de helanca ou de algodão (preferível) nesta operação, bem como em toda manipulação que se faça da película. A higienização química deve ser feita apenas em material com alta proliferação fúngica.

Nessa fase do trabalho, é comum a ocorrência de quebras na película - ou descolamento de emendas, resultante de montagem fílmica anterior. A película arrebenta em alguns pontos e eles devem ser colados.

Para essa pequena ação de preservação é necessário o uso de alguns instrumentos, além de adesivo apropriado. Usa-se, inicialmente, uma cortadeira/raspadeira, ferramenta que corta de forma retilínea os extremos da fita partida a serem reunidos. Ao mesmo tempo, tal instrumento raspa a fita para que seja aplicada a cola no pequeno espaço raspado.

Em seguida, as extremidades a serem unidas são encaixadas em uma coladeira, objeto que recebe a película para que nela seja aplicado o adesivo (especial para filmes); depois de aplicada a cola, há um dispositivo que é colocado como um peso sobre a emenda formada. Essa mini prensa deve agir sobre o reparo por cerca de 30 minutos.

\section{Acondicionamento e guarda}

O maior problema no acondicionamento de películas é a aceleração do que se chama de "síndrome do vinagre". O acondicionamento de filmes em latas metálicas provoca uma reação química envolvendo o ácido acético e faz com que ele solte um odor acre, de vinagre. $A$ reação do metal com as substâncias formadoras da imagem (sais de prata e ligantes) faz com que o filme exale tal cheiro. Esse processo de deterioração tem como principal característica, então, poder ser detectado através do olfato.

\section{Soluções de acondicionamento}

Para interromper a "síndrome do vinagre", deve-se trocar a lata (metal) por embalagens plásticas. Quando isto se torna difícil ou impossível, uma solução é envolver o rolo de filme em invólucro de polietileno, minimizando seu contato com o metal.

Esses rolos podem estar em botoques (miolo do rolo) ou em bobinas (carretéis), que devem ser sempre de material plástico para evitar que ranhuras metálicas risquem e danifiquem as películas. Ademais, o carretel plástico é mais maleável, não amassa nem enferruja, situações que também poderiam afetar o filme enrolado em bobina metálica. 


\section{Mobiliário para guarda}

Os móveis para guarda de películas devem ser, preferencialmente, de metal (pelos mesmos motivos relacionados à guarda de fotografias).

Se as caixas de acondicionamento forem de plástico, a guarda vertical é favorecida, mas só é indicada se os rolos forem periodicamente mudados de posição dentro da caixa, para evitar que o peso provoque lombadas localizadas.

As embalagens metálicas, as latas do tipo "pizza" devem ser guardadas na horizontal, empilhadas cinco a cinco; a guarda horizontal proporciona total planificação do rolo, evitando qualquer deformação.

\section{Climatização e monitoramento ambiental}

A área de guarda de películas deve permanecer a uma temperatura entre 18 e $21^{\circ} \mathrm{Ce}$ com umidade relativa de $50 \%$. Para isto devem ser usados equipamentos de ar condicionado e desumidificadores.

O monitoramento ambiental deve ser feito com termohigrógrafo e psicrômetro (giratório ou de aspiração).

O principal cuidado se refere à possibilidade de presença de películas à base de nitrato de celulose, com sua característica autocomburente. O nitrato, quando submetido a temperaturas próximas a $40^{\circ} \mathrm{C}$, pode entrar em autocombustão, colocando em risco todo o acervo.

\section{Equipamentos para o tratamento de películas}

Além dos instrumentos de climatização, das ferramentas de reconstituição de emendas (cortadeira-raspadeira e coladeira) e da moviola (para melhor manipulação do rolo do filme), outros equipamentos podem servir à identificação do conteúdo da película (assunto que não será abordado neste artigo). Os equipamentos auxiliares são o negatoscópio (mesa de luz algumas vezes embutida na moviola) e a leitora de som.

O negatoscópio - ou mesa de luz - permite que se identifique a cromia do filme e, por vezes, cenas e/ou atores.

A leitora de som é útil na verificação da presença ou não de fundo musical, na identificação do idioma do filme e do teor dos diálogos e elocuções.

\section{Fitas de vídeo e fitas de áudio}

Esta parte tratará de dois grupos de espécies documentais que possuem muitas semelhanças entre si: fitas de vídeo e fitas de áudio. 
As fitas de vídeo incluem os formatos VHS (Video Home System, ou vídeo doméstico), Betamax (também caseiro, mas não tão bem-sucedido), U-Matic (de uso comercial e profissional) e Betacam (também de uso profissional).

As fitas de áudio, por sua vez, abarcam os cassetes, as fitas em rolo (de milimetragem variável) e as fitas DAT (Digital Audio Tape).

Características do material

As fitas magnéticas têm uma característica intrínseca de deterioração muito importante a ser considerada. Tais documentos, para serem "lidos", necessitam de equipamentos de reprodução. Esses equipamentos têm uma relação "violenta" com as fitas; as conhecidas cabeças dos equipamentos de vídeo e os cabeçotes dos tapes e toca-fitas, para realizar as leituras de imagem e som, respectivamente, fazem isto de maneira muito agressiva. Cada vez que se coloca uma fita no vídeo ou no gravador, ela sofre um desgaste considerável.

Em contrapartida, as fitas magnéticas são facilmente reproduzíveis, principalmente com finalidade de preservação e de acessibilidade à pesquisa.

Higienização

A higienização de fitas magnéticas se dá de maneira peculiar. Em vez de se limpar a própria fita, deve-se limpar o equipamento de leitura. Os cabeçotes e cabeças de gravação/reprodução devem ser limpos periodicamente (a cada 100 fitas tocadas/assistidas), de preferência por técnico especializado. Por esse motivo, é preciso ter controle do equipamento onde a fita será reproduzida; por isso, também, é importante ter o acervo todo copiado, para que as cópias sejam emprestadas e os originais preservados.

Deve-se ressaltar que as substâncias comercializadas no mercado (fitas de limpeza) não são recomendadas para uso que vise à preservação.

A higienização da fita em si é feita através da sua rolagem (rebobinagem) no equipamento (de preferência no modo play, embora o modo forward seja utilizado em acervos muito numerosos). A cada 100 fitas roladas, os cabeçotes devem ser limpos.

A rolagem da fita deve ser feita a cada três anos (em fitas de áudio em cassete e em fitas de vídeo VHS) e a cada cinco anos (em fitas de vídeo U-Matic), para evitar aderência (entre outros problemas). 
Acondicionamento e guarda

\section{Soluções de acondicionamento}

As fitas magnéticas são acondicionadas, normalmente, em suas caixas originais, que são de plástico. Porém, não raro aparecem nos acervos algumas fitas destituídas de suas caixas. Quando isto acontece, recomenda-se que sejam confeccionadas caixas de papel neutro.

\section{Mobiliário}

Como as fitas de áudio e vídeo são magnéticas, aconselha-se que sejam guardadas em armários de madeira tratada ou em armários de metal tratados com tinta epóxi (antidesmagnetizante). Os campos magnéticos provocam perda de sinal de áudio e de vídeo, ou seja, sons e imagens somem, configurando-se uma deterioração irreversível.

\section{Climatização e monitoramento ambiental}

É importantíssimo que a área de guarda seja climatizada, principalmente se o mobiliário for de madeira, mesmo se ela for tratada. A temperatura deve variar entre $18^{\circ} \mathrm{C} \mathrm{e}$ $21^{\circ} \mathrm{C}$ e a umidade relativa não deve ser maior que $50 \%$. O uso do desumidificador, do esterilizador e dos equipamentos de monitoramento ambiental é igualmente recomendado.

\section{Discos}

Características do material

Os discos podem ser, principalmente, de acetato, goma laca ou vinil. Os de acetato são, sem dúvida, os menos estáveis e mais difíceis de conservar. A base era geralmente de alumínio, mas também se tem notícia do uso de vidro e de papelão; essa base era revestida de nitrocelulose plastificada e de óleo de rícino. Com o tempo - e altas temperaturas e umidade relativa elevada -, a degradação desse plastificante era provocada pela contração da nitrocelulose: o revestimento começava a ficar quebradiço, desprendendo-se da base e causando perda irreversível de informação sonora.

Os discos de goma-laca foram criados na década de 1890 e são estáveis, em sua maioria. A grande dificuldade de se aplicar regras de preservação está no fato de que a gomalaca era, na verdade, o revestimento de uma base feita geralmente de uma variedade de materiais. Além disso, a goma-laca costumava constituir cerca de $20 \%$ da formulação, sendo o restante de uma gama variada de outros materiais, devido às experiências feitas no início desta tecnologia e à diversidade de fabricantes que produziram tais discos do final do século XIX até meados do século XX. Muitos desses materiais continham componentes orgânicos, 
tornando o disco alvo de ataques de fungos, ainda que a goma-laca propriamente dita seja resistente a eles.

Os discos de vinil foram gradualmente substituindo os de goma-laca a partir de 1950, sendo considerados de alto grau de preservação, podendo durar mais de 100 anos, se guardados em ambiente adequadamente climatizado.

O vinil - na verdade, policloreto de vinila misturado com outros plastificantes, substâncias antiestáticas, pigmentos, estabilizadores, acetato de vinila e outros enchimentos é particularmente sensível à luz ultravioleta e ao calor.

Higienização

A higienização de discos se dá de maneira peculiar e pode ser chamada de "o banho do bebê".

Em primeiríssimo lugar, deve-se fazer todo o registro das informações contidas no selo do disco, para evitar perdas causadas pelo banho. Em seguida, aplica-se uma pequena gota de xampu neutro infantil sobre um dos lados do disco. Esfrega-se com escova de cabelo de bebê (cerdas macias) ${ }^{15}$ embebida em água destilada, fazendo movimentos circulares, no sentido dos sulcos do disco. Repete-se esse movimento do outro lado do disco (avaliando a necessidade ou não de aplicação de mais uma gota de xampu, a depender do estado de sujidade do material).

Depois de ensaboado, o disco deve ser enxaguado em água destilada abundante, de forma a remover qualquer sinal de xampu. A seguir, coloca-se o disco para secar em escorredor de pratos de plástico revestido de papel mata-borrão virgem (primeiro uso) por 24 horas, em ambiente climatizado, lembrando-se de virar o disco verticalmente após as primeiras 12 horas.

\section{Acondicionamento e guarda}

\section{Soluções de acondicionamento}

As capas originais de discos muito antigos (aquelas com um buraco no meio, para visualização do selo) são feitas de papel altamente ácido e devem ser removidas (não sem antes colher toda informação necessária ao tratamento da informação) e guardadas separadamente.

\footnotetext{
${ }^{15}$ Ver exemplo de escova de bebê em: <http://hannahcosplayer.blogspot.com.br/2012/12/desembaracarperuca.html>. Acesso em: 07 dez. 2015.
} 
Cada disco deve ser colocado em envelope de polietileno (aquele plástico que sempre embala os discos de vinil). Podem ser confeccionadas caixas de papel neutro onde caibam cinco destes discos.

\section{Mobiliário}

As caixas devem ser guardadas verticalmente, em estantes de madeira tratada ou em armários de metal tratados com tinta polimerizada epóxi.

\section{Climatização e monitoramento ambiental}

Em altas temperaturas e umidade relativa elevada, os discos de acetato liberam ácido palmítico, que é uma substância branca e gordurosa como cera, que torna o acetato especialmente suscetível ao ataque de fungos.

Se submetidos a condições inadequadas de climatização (alta umidade relativa), os discos em goma-laca podem se tornar facilmente quebradiços. Essa condição de deterioração pode ser observada, caso haja presença de um pó fino preto após a reprodução do disco; esse pó é informação sonora se esvaindo das ranhuras do disco.

Os discos de vinil, por serem particularmente sensíveis às radiações luminosas e ao calor, podem sofrer deformações - geralmente onduladas - irreversíveis e cumulativas, prejudicando parcial ou totalmente a reprodução e compreensão da informação sonora. Em contrapartida, são resistentes a ataques de fungos e a altas taxas de umidade.

\section{Outros materiais especiais}

Não é raro que surjam artefatos tridimensionais nos acervos. Eles podem variar desde jogos de tabuleiro, passando por estátuas e/ou esculturas chegando às medalhas; nessa categoria ainda se pode encontrar: flâmulas, moedas, peças decorativas, quadros, modelos, moedas, máquinas, indumentária (roupas, vestimentas, calçados e acessórios) e artigos resultantes de colecionadores especializados (tampinhas de garrafa, latas de cervejas, chaveiros, cartões telefônicos, manoplas de câmbio de automóvel, bonecas, brinquedos e uma lista interminável de possibilidades).

A variedade de espécies documentais também leva a uma variedade de materiais constituintes desses artefatos, tais como: madeira (e seus vários tipos), papel (e seus vários tipos), cerâmica, acrílico, plástico (e seus vários tipos), metal (e seus vários tipos), tecido (e seus vários tipos), couro etc. Alguns desses objetos, inclusive, podem conter mais que um material, como, por exemplo, um jogo de gamão com tabuleiro em madeira de pau-marfim e peças em ébano e marfim, acondicionado em caixa de madeira comum. 
Por conseguinte, os cuidados de conservação preventiva e de preservação também deverão ser especializados para cada tipo de objeto e de material, sendo o mais recomendável sempre procurar um especialista para realizar qualquer intervenção, mesmo que de higienização.

Há dois casos particularmente curiosos verificados em acervo múltiplo composto de objetos. O primeiro se refere a um jogo de xadrez cujas peças foram confeccionadas com miolo de pão, provavelmente entre as décadas de 1960 e 1970. Com o passar do tempo, os objetos, submetidos a condições inadequadas de acondicionamento, guarda e climatização, sofreram o ataque de brocas, que se alimentaram de boa parte das peças. Outro caso trata de um conjunto de três tijolos em cerâmica, resultantes de demolição de importante edificação, que, por nunca estarem acondicionados e sempre afastados dos demais materiais do acervo (por soltarem seu pó avermelhado), sempre foram vítimas do pessoal encarregado da limpeza de determinada instituição: eram levados ao lixo - e de lá trazidos em seguida - a cada vez que se mudava de funcionário.

Outra espécie que quase se enquadraria nos tridimensionais é a realia: trata-se de objetos encontrados na natureza e que possuem a particular característica de ser informação e suporte a um só tempo. São espécimes botânicos (herbários e coleções de sementes), zoológicos (coleções de coleópteros, borboletários e animais empalhados) e minerais (gemas, rochas e pedras preciosas). Cada um desses tipos de realia requer uma ação de preservação, a depender de seu material constituinte.

Outras espécies que se pode encontrar num acervo são plantas, croquis, mapas e cartazes. Por serem constituídos de papel em sua maioria (podendo ser de plástico também), devem ser tratados como os outros documentos em papel, lembrando apenas que sua guarda deve ser feita preferencialmente em mapotecas, por causa de suas dimensões.

A partir da década de 1990, os acervos passaram a receber também disquetes, CDROM e DVD. Os disquetes, formados por plástico e material magnético, obedecem ao mesmo tratamento das fitas de vídeo e de áudio; os outros são a combinação de plásticos, acrílicos e metais. A principal característica dessas espécies é que sua rápida obsolescência não permite que se saiba qual sua real expectativa de vida.

\section{Controvérsias preciosas}

Cartão postal: fotografia ou correspondência?

Os cartões postais são compostos de uma imagem (ou de uma manifestação literária) na parte frontal e de um espaço destinado a texto e endereços em seu verso. Essas 
características geram algumas dúvidas quanto ao tratamento a ser aplicado - mais em suas informações que em seu suporte, mas importantes para saber a localização dessa espécie documental no acervo.

Alguns cartões postais são originariamente confeccionados como fotografias e merecem tratamento idêntico ao já apontado no início deste texto; outros são pinturas, desenhos, gravuras e resultante de artes plásticas, devendo ser tratados de forma que se privilegie o tratamento da imagem; há, inclusive, cartões postais confeccionados artesanalmente, com colagens, que trazem, por vezes, pedaços de objetos da natureza (pétalas, folhas, cascas de árvore, asas de borboleta etc.) que necessitam de tratamento adequado de preservação.

Ainda que se dê a chancela de correspondência (ativa ou passiva) aos cartões postais, será sempre necessário observar tal particularidade da composição de seu frontispício.

Digitalização de imagens fotográficas

Assim que a expansão informática teve início, uma verdadeira febre invadiu alguns acervos: todos queriam digitalizar suas fotografias, tanto com finalidade de preservação quanto para melhorar o acesso.

Naquele momento (segunda metade da década de 1990), os equipamentos de escâner ainda não eram dotados de luzes especiais e emitiam radiação altamente prejudicial às fotografias, especialmente às albuminas.

As instituições que optaram por digitalizar suas fotografias - sabendo ou não desse detalhe catastrófico - provocaram o envelhecimento de suas imagens em vários anos apenas ao acionar uma vez a máquina. Ressalte-se, contudo, que o mais importante é sempre cuidar primeiramente dos negativos, visto que são as matrizes fotográficas. Outro conselho importante antes de se iniciar um projeto de reprografia do acervo - seja micrográfica ou digital - é tratar primeiramente a informação contida nos documentos.

Climatização de acervos fora do horário comercial

Assunto controverso em fóruns e debates é o liga-desliga de equipamentos de ar condicionado nas instituições.

Quem defende que o equipamento deve permanecer ligado por 24 horas ininterruptas alega que, desta forma, os documentos estarão sempre em condições climáticas adequadas e livres de danos causados por calor, umidade e ataque de insetos e micro-organismos.

É de se alertar, entretanto, que muitos incêndios em acervos podem ter sido provocados por curto-circuito em equipamentos de ar condicionado, especialmente em máquinas sem manutenção periódica. Em maio de 2010, o Instituto Butantã da Universidade 
de São Paulo perdeu parte de seu acervo herpetológico nessas circunstâncias; outros tristes exemplos são o acervo fotográfico do Centro de Documentação do jornal Correio Braziliense (março de 2003), as obras do artista plástico Hélio Oiticica (outubro de 2009, Rio de Janeiro) e o acervo histórico da Universidade Federal do Rio de Janeiro (março de 2011).

Uma boa solução para instituições que não possuem vigilância noturna - contando com a presença de alguém que possa detectar um princípio de incêndio - é equacionar a situação da seguinte maneira: se o equipamento de ar condicionado puder refrigerar a área de guarda durante oito horas de trabalho dos profissionais, pode ser que o suposto "ar quente" demore tanto para chegar aos itens documentais que o novo dia de trabalho já estará tendo início e o ar condicionado voltará a ser ligado. Ou seja: o microclima - clima de área pequena em torno do item documental (uma fotografia dentro de uma jaqueta de poliéster, dentro de uma pasta suspensa, dentro de uma gaveta do armário de aço) levará algumas horas pare ser afetado pela falta de refrigeração. Some-se a isto o fato de que a temperatura externa cai durante o período de fechamento das instituições.

\section{Considerações finais}

Tudo agora se pode digitalizar facilmente, mas não há recursos suficientes nos rincões do Brasil nem para o básico tradicional. Em arquivos permanentes (históricos) e em museus, quase sempre é preciso ter o original.

Nada é absoluto na ciência e isto não é diferente na área de conservação e preservação documental. No Brasil, onde há inúmeros acervos espalhados pelo interior dos estados, em situação altamente precária de tratamento tanto do suporte quanto da informação, deve-se sempre apelar para a criatividade para se poder atingir minimamente o ideal estipulado pelas regras tão cruéis dessa área - vamos combinar que os conservadores são considerados sempre uns chatos, com os seus "isto pode" e "isto não pode" a perseguir colegas de trabalho e usuários do acervo!

Rasteira maior trouxe a revolução informática com os exageros da obsolescência, que nos torna a todos ignorantes cotidianos, uma vez que a velocidade das novidades do mundo eletrônico ultrapassa de longe qualquer outro desenvolvimento tecnológico de que se tem notícia na história da humanidade.

Boaventura Sousa Santos afirma que "o objecto é a continuação do sujeito por outros meios. Por isso, todo o conhecimento científico é autoconhecimento" (SANTOS, 1987, p. 52). 0 colega lusitano oferece também a recíproca: "A condição epistemológica da ciência repercutese na condição existencial dos cientistas. Afinal, se todo o conhecimento é autoconhecimento, 
também todo o desconhecimento é auto-desconhecimento" (SANTOS, 1987, p. 58). Nossa ignorância pode nos fazer ignorantes de nós mesmos.

Uma história exemplar destas que acontecem no ambiente de trabalho ocorreu na década de 1990. Um acervo recebeu uma doação considerável de fitas de áudio em cassete. Elas pertenciam a um deficiente visual e apresentavam gravações de trabalhos de alunos, dissertações, teses e até diversos livros importantes da área de ciências humanas, lidos em voz alta por sua esposa e amigos.

Imbuída de sua contumaz eficiência, durante as horas extras noturnas, uma auxiliar livrou cada uma das fitas de um "pedacinho inútil de papel furadinho", cuidadosamente depositado entre a caixa e o papel que guarda comumente as fitas cassete: desmembrou e jogou no lixo toda a identificação em Braile... Os relevos formados pela anagliptografia, com a ação do tempo, ficaram marcados e perfuraram o papel em algumas partes; pensando ser aquilo uma coisa inútil qualquer, a funcionária de desfez do "supérfluo".

Será que não se cometem enganos como esse no tratamento digital dos acervos, ao manipular eletronicamente imagens, ao gerenciar, enfim, bancos de dados e de imagens?

Talvez a solução - ou o caminho para ela - seja a mais simples e elementar troca de experiências, algo que o mundo virtual promoveu com o aumento do acesso à informação, mas que também tem colocado em risco, ao retirar do humano o contato pessoal.

\section{Referências}

ABREU, Ana Lúcia de. Acondicionamento e guarda de acervos fotográficos. Rio de Janeiro: Fundação Biblioteca Nacional, 2000. (Série Documentos Técnicos, 5).

ANDRADE, Ana Célia N. Microfilme: passado, presente e futuro da preservação documental, in Registro: Revista do Arquivo Público Municipal de Indaiatuba, v. 3, n. 3, p. 51-60, 2004.

ANDRADE, Maria de. A restauração digital de Macunaíma. Rio de Janeiro: Filmes do Serro, 2006. (15', DVD).

BARUKI, Sandra. Projeto experimental; preservação fotográfica. Rio de Janeiro: Universidade Federal Fluminense, 1990. Mimeo.

BURGI, Sérgio. A preservação dos materiais fotográficos: o processamento para permanência. Revista Fotóptica, São Paulo, n. 120, p. 2/42/45, s.d.

BURGI, Sérgio. Introdução à preservação e conservação de acervos fotográficos; técnicas, métodos e materiais. Rio de Janeiro: Ministério da Cultura/FUNARTE, 1988.

EDMONDSON, Ray. Uma filosofia de arquivos audiovisuais. In: UNESCO. Programa Geral de Informação e UNISIST. Paris: Unesco, 1998. 60 p.

FIGUEIRA, Nisiclér M. Videocassete: a história em cores; fácil produção difícil conservação. Acervo, Rio de Janeiro, v. 7, n. 1-2, p. 97-106, 1994. 
GONZÁlEZ GARCÍA, Pedro. Los documentos en nuevos soportes. Boletim do Arquivo, São Paulo, v. 1, n. 1, p. 19-37, 1992.

HENDRICKS, Klaus B. Armazenagem e manuseio de materiais fotográficos. Cadernos Técnicos de Conservação Fotográfica, Rio de Janeiro, FUNARTE, n. 4, p. 1-15, 1997.

HOLLÓS, Adriana Cox. A preservação de filmes no Arquivo Nacional. Acervo, Rio de Janeiro, v. 16, n. 1, p. 103-110, 2003.

HORTA, João Carlos. Negativos de vidro: conservação. Rio de Janeiro: Centro de Conservação e Preservação Fotográfica, 1993. (18', DVD).

KODAK. B/W processing for permanence. Rochester: Eastman Kodak Company (Kodak Pamphlet n. J-19), s. d.

LEPÍSCOPO, Marcos, TRIGO, Thales. História da fotografia 1840-1960. São Paulo: Editora SENAC, 1998. (CD-ROM)

LOPES, Luís F., MONTE, Antônio C. A qualidade dos suportes no armazenamento de informações. Florianópolis: VisualBooks, 2004.

MANINI, Miriam P. Relatório de treinamento em preservação e conservação fotográfica. Campinas, 1993. Mimeo.

Relatório do IV Treinamento em Conservação e Preservação Fotográfica. Rio de Janeiro, 1994a. Mimeo.

Relatório das oficinas de conservação e preservação de fotografias ministradas por Nora Kennedy e Peter Mustardo. Rio de Janeiro, 1994b. Mimeo.

Os usos da iconografia no ensino e na pesquisa: o acervo multimeios do Arquivo Edgard Leuenroth. Cadernos AEL, Campinas: AEL/IFCH, n. 5/6, p. 221-244, 1997.

O futuro do passado: acervos fotográficos tradicionais + acervos fotográficos eletrônicos. Anais do Museu Paulista, São Paulo, v. 12, p. 55-61, 2004.

A tradição e os novos desafios para a conservação/preservação das informações arquivísticas. Cadernos do CEOM, Centro de Memória do Oeste de Santa Catarina, v. 18, n. 22, p. 169-175, dez. 2005.

A fotografia como registro e como documento de arquivo. In: BARTALO, Linete; MORENO, Nádina A. (org.). Gestão em Arquivologia; abordagens múltiplas. Londrina: EDUEL, 2008. p. 119-183.

MELLO, Márcia; PESSOA, Maristela. Manual de acondicionamento de material fotográfico. Rio de Janeiro: FUNARTE/IBAC, 1994.

MUÑOZ VIÑAS, Salvador. Contemporary theory of conservation. Oxford: Elsevier, 2005.

MUSTARDO, Peter. Preservação de fotografia na era eletrônica. Cadernos Técnicos de Conservação Fotográfica, Rio de Janeiro: FUNARTE, n. 2, p. 9-12, 1997.

OLIVEIRA, João Sócrates. Manual prático de preservação fotográfica. Revista de Museologia, São Paulo, Instituto de Museologia de São Paulo/FESP, v. 1, n. 1, p. 51-61. 1989.

Preservação e restauração de registros de imagens. In: SEMINÁRIO NACIONAL DE ARQUIVOS UNIVERSITÁRIOS, 1., Campinas, 1991. Mimeo.

Trabalhando com filmes de segurança deteriorados. Acervo, Rio de Janeiro, v. 16, n. 1, p. 83-94, 2003.

PARENTE, José Inácio. Rio de memórias. Brasil, 1987. (Filme, 33’). 
PAVÃO, Luís. Conservação de fotografia - o essencial. Cadernos Técnicos de Conservação Fotográfica, Rio de Janeiro, FUNARTE, n. 3, p. 7-12, 1997.

PEROTA, Maria Luiza L. R. (org.) Multimeios; seleção, aquisição, processamento, armazenagem, empréstimo. 4a ed. Vitória: EDUFES, 1997.

PROGRAMA Conservação Preventiva em Bibliotecas e Arquivos. Disponível em: <http://www.arqsp.org.br/cpba/>. Acesso em: 07 dez. 2015.

REILLY, James M. Care and identification of 19th-century photographic prints. Rochester: Eastman Kodak, 1986.

REMÉDIO, Maria A. Controle do ataque de insetos em bibliotecas e arquivos: uma experiência com CO2 e N2. Registro: Revista do Arquivo Público Municipal de Indaiatuba, v. 1, n. 1, p. 6670, 2002.

RIBEIRO, Fernanda. Os Arquivos na era pós-custodial: reflexões sobre a mudança que urge operar. In: ENCONTROS DO OUTONO - MEMÓRIA, HISTÓRIA E PATRIMÔNIO - BIBLIOTECAS, ARQUIVOS E MUSEUS, 4., Vila Nova de Famalicão, Casa das Artes, 26 e 27 out. 2001. Comunicação.

Gestão da informação/preservação da memória na era pós-custodial: um equilíbrio precário? In: JORGE, Vítor Oliveira (org.). Conservar para quê? Porto, Coimbra: Faculdade de Letras da Universidade do Porto, Centro de Estudos Arqueológicos das Universidades de Coimbra e Porto, 2005. (Separata).

SANTOS, Boaventura Sousa. Um discurso sobre as ciências. 8ª ed. Porto: Afrontamento, 1987.

SAUSP. Manual de conservação preventiva de documentos; papel e filme. São Paulo: EDUSP, 2005. (Acadêmica, 63).

UNESCO. Recomendações sobre a salvaguarda e a conservação das imagens em movimento. Paris: Unesco, 1980.

ZÚÑIGA, Solange Sette G. Centro de Conservação e Preservação Fotográfica. Acervo: Revista do Arquivo Nacional, Rio de Janeiro, v. 6, n. 1/2, p. 155-162, jan. /dez. 1994.

Recebido/Recibido/Received: 2015-12-14.

Aceitado/Aceptado/Accepted: 2016-04-28. 